\title{
EFEKTIFITAS PEMBERIAN PERMEN JAHE TERHADAP MUAL MUNTAH PADA IBU HAMIL DI KLINIK KHAIRUNIDA SUNGGAL TAHUN 2018
}

\author{
Ani Nurdiana \\ Jurusan Kebidanan, Poltekkes Kemenkes RI Medan \\ Aninurdiana63@gmail.com
}

\begin{abstract}
Abstrak
Kehamilan menyebabkan banyak perubahan pada tubuh ibu, maka akan muncul berbagai macam ketidaknyamanan secara fisiologis pada ibu misalnya mual muntah, biasanya bersifat ringan dan merupakan kondisi yang dapat dikontrol sesuai dengan kondisi ibu. Kondisi tersebut kadang berhenti pada trimester pertama, namun pengaruhnya dapat menimbulkan gangguan nutrisi, dehidrasi, kelemahan, penurunan berat badan, dan ketidakseimbangan elektrolit, bila tidak ditangani maka akan bertambah berat menjadi Hiperemesis Gravidarum. Penelitian ini bertujuan untuk mengetahui efektifitas permen jahe dalam penurunan frekuensi mual muntah pada ibu hamil trimester pertama di klinik khairunida dengan rancangan penelitian Quasy Eksperimental dengan desain One Group Pretest Posttest. Responden yang digunakan berjumlah 15 orang dengan teknik purposivesampling. Data ini diambil menggunakan uji T-dependent. Dari hasil penelitian menunjukkan nilai frekuensi mual muntah sebelum diberikan intervensi yaitu 10,93 dan setelah diberikan intervensi yaitu 3,33 dengan penurunan rata-rata 7,60. Hasil uji statistik didapatkan nilai $p<(0,05)$ sehingga dapat disimpulkan bahwa pemberian permen jahe efektif dalam penurunan mual muntah pada ibu hamil trimester pertama. Diharapkan peneliti selanjutnya dapat mengurangi penggunaan obat non farmakologi untuk mengatasi mual muntah pada ibu hamil trimester pertama dan berkolaborasi dengan jurusan farmasi untuk memudahkan dalam proses pembuatan dan menghasilkan permen jahe yang berkualitas baik.
\end{abstract}

Kata kunci: Permen Jahe, mual muntah

\section{PENDAHULUAN}

Berdasarkan data dari World Health Organization (WHO) tahun 2015, setiap hari sekitar hampir 830 wanita meninggal akibat hal terkait dengan kehamilan dan persalinan. 99\% dari seluruh kematian ibu terjadi di Negara berkembang, terutama yang tinggal di daerah pedesaan dan diantara masyarakat miskin (WHO, 2015).

Millenium Development Goals (MDGs) dengan masa berlaku 5 tahun menargetkan Angka Kematian Ibu (AKI) sebesar 102/100.000 Kelahiran Hidup (KH) ternyata kurang berhasil hal ini dikarenakan program MDGs yang berjalan sangat lambat, sehingga tahun 2016 diluncurkan Sustainable Development Goals (SDGs) sebagai suatu pembangunan berkelanjutan dengan agenda baru, pada tahun 2030 mengurangi AKI menjadi 70/100.000 KH (Kemenkes, 2015).

Berdasarkan laporan dari profil Kab/Kota AKI maternal yang dilaporkan di Sumatera Utara tahun 2015 hanya 93/100.000 KH (Profil Kesehatan Sumut, 2015).

Kehamilan menyebabkan banyak perubahan fisik, Psikis dan hormonal pada tubuh ibu. Hal tersebut menimbulkan bermacam-macam keluhan, salah satunya adalah mual muntah yang biasa terjadi pada awal kehamilan (Putri, Ayu 2016).

Mual muntah yang terjadi pada kehamilan yang disebabkan karena terjadi peningkatan kadar hormon estrogen dan progesteron yang diproduksi oleh Human Chorionic Gonadotropine (HCG) dalam serum dalam dari plasenta. Mual dan muntah terjadi pada $60-80 \%$ primigravida dan 40-60\% pada multigravida. Perubahan hormon pada setiap perempuan hamil responnya akan berbeda, sehingga tidak semua mengalami mual muntah pada kehamilan (Putri, Ayu 2016).

Mual dan muntah pada kehamilan biasanya bersifat ringan dan merupakan kondisi yang dapat dikontrol sesuai dengan kondisi ibu hamil. Kondisi tersebut kadang berhenti pada trimester pertama, namun pengaruhnya dapat menimbulkan gangguan nutrisi, dehidrasi, kelemahan, penurunan berat badan, serta ketidakseimbangan elektrolit, bila tidak ditangani mual muntah ini akan bertambah berat menjadi Hiperemesis Gravidarum. Mengatasi mual muntah selama masa kehamilan dapat dilakukan melalui tindakan farmakologi maupun non farmakologi. Tindakan non farmakologi yang biasa disarankan oleh tenaga kesehatan seperti menganjurkan ibu hamil untuk 
mengkonsumsi jahe dalam bentuk teh jahe, teknik relaksasi, dan aromaterapi (Ardani, Ayu 2014).

Secara psikologis, mual dan muntah selama kehamilan mempengaruhi lebih dari 80\% wanita hamil serta menimbulkan efek yang signifikan terhadap quality of life. Sebagian ibu hamil merasakan mual dan muntah merupakan hal yang biasa terjadi selama kehamilan. Sebagian lagi merasakan sebagai sesuatu yang tidak nyaman dan mengganggu aktivitas seharihari (Rofi'ah, Handayani, Rahmawati 2017).

Bahkan banyak wanita hamil yang harus mengkonsumsi obat-obatan atau tindakan alternatif lain untuk mengatasi mual dan muntah. Obat anti mual yang sering diberikan pada wanita hamil adalah vitamin B6. Namun obat ini dilaporkan memiliki efek samping seperti sakit kepala, diare, dan mengantuk (Rofi’ah, Handayani, Rahmawati 2017).

Terapi awal pada emesis sebaiknya konservatif disertai dengan perubahan diet, dukungan emosional, dan terapi alternatif seperti herbal. Ramuan tradisional bisa digunakan dengan meminum secangkir jahe hangat. Di India, jahe dibuat sebagai minuman untuk mengatasi rasa mual pada wanita hamil. Jahe dapat dikonsumsi dalam berbagai bentuk seperti minuman, permen, atau manisan (Rofi'ah, Handayani, Rahmawati 2017).

Jahe adalah tanaman dengan sejuta khasiat yang telah dikenal sejak lama. Jahe merupakan salah satu rempah penting. Rimpangnya sangat banyak manfaatnya, antara lain sebagai bumbu masak, minuman, serta permen dan juga digunakan dalam ramuan obat tradisional.

Kandungan kimia di dalam jahe yang dapat mengatasi mual muntah diantaranya yaitu minyak atsiri yang mempunyai efek menyegarkan dan menghasilkan aroma sehingga memblokir reflek muntah. Oleoresisnya menyebabkan rasa pedas yang menghangatkan tubuh dan mengeluarkan keringat. Efek antiemetik juga ditimbulkan oleh komponen diterpentenoid yaitu gingerol, shaogaol, galanolactone (Putri, Ayu 2016).

Dosis jahe sebaiknya tidak lebih dari 2 gr per hari, karena bisa memicu keguguran (Budhwaar, 2006, hlm.26) dalam Fitria, Rahmi 2013).

Berdasrkan survey awal di Klinik KHAIRUNIDA 3 dari 5 ibu hamil trimester pertama mengalami mual muntah. Berdasarkan Latar Belakang diatas, maka penulis tertarik untuk melakukan penelitian tentang Pengaruh Permen Jahe Terhadap Penurunan Mual dan Muntah pada Ibu Hamil Trimester Pertama di Klinik Khairunida Sunggal.

\section{METODE}

Penelitian ini merupakan jenis penelitian Quasy Eksperimental dengan desain One Group Pretest Posttest. Dalam desain ini sebelum perlakuan diberikan, terlebih dahulu sampel diberi pretest (tes awal) dan sesudah eksperimen sampel diberi posttest (tes akhir). Sampel yang diambil adalah 15 ibu hamil trimester pertama di Klinik
Khairunida, yaitu setiap ibu hamil yang memenuhi kriteria Bersedia menjadi responden, Ibu hamil trimester pertama (0-12 minggu) yang mengalami mual muntah $(+)$ normal yakni $<10$ kali/hari yang datang ke Klinik Khairunida Sunggal, Tidak sedang mengkonsumsi obat anti muntah, Tidak ada riwayat abortus,Tidak memiliki penyakit komplikasi. Analisa data dilakukan dengan menggunakan uji statistik uji t-dependent.

\section{HASIL}

\section{A.1 Analisa Univariat}

Karakteristik responden dari 15 responden yang melakukan pemeriksaan ANC di klinik Khairunida Sunggal.

Tabel 4.1

Distribusi responden berdasarkan karakteristik responden

\begin{tabular}{cccc}
\multicolumn{4}{c}{$(\mathrm{N}=15)$} \\
\hline No & Karakteristik & $\mathrm{F}$ & $\%$ \\
1 & Umur & & \\
& $<20$ tahun & 3 & 20.0 \\
& $20-35$ tahun & 12 & 80.0 \\
& & & \\
2 & Pendidikan & & 6.7 \\
& SMP & 1 & 93.3 \\
& SMA & 14 & \\
& Pekerjaan & & 86.7 \\
& IRT & 13 & 13.3 \\
4 & Wiraswasta & 2 & 53.3 \\
& Paritas & & \\
& G1PoAo & 8 & 26.7 \\
& G2P1Ao & 4 & 20.0 \\
\hline
\end{tabular}

Berdasarkan tabel 4.1 diketahui dari 15 responden ibu hamil trimester pertama mayoritas berusia 20-35 tahun, mayoritas responden berpendidikan SMA, mayoritas responden bekerja sebagai Ibu Rumah Tangga, dan mayoritas responden belum memiliki anak atau baru mengalami kehamilan.

Tabel 4.2

Kategori mual muntah sebelum dan sesudah intervensi $(\mathrm{N}=15)$

\begin{tabular}{ccccc}
\hline No & intervensi & Kategori & F & \% \\
\hline $\mathbf{1}$ & Sebelum & Sedang & 2 & 13,3 \\
& & Berat & 13 & 86,7 \\
$\mathbf{2}$ & \multirow{2}{*}{ Sesudah } & Tidak & 11 & 73,3 \\
& & muntah & & \\
& & Ringan & 4 & 26,7 \\
\hline
\end{tabular}

Berdasarkan tabel 4.2 mayoritas responden berada dalam kategori mual muntah berat sebelum dilakukan intervensi. Setelah dilakukan intervensi mayoritas responden berada dalam kategori tidak mengalami mual muntah. 


\section{A.2 Analisa Bivariat}

Analisa bivariat dalam penelitian ini bertujuan untuk mengetahui perbedaan nilai mual muntah sebelum intervensi dan setelah intervensi dengan menggunakan uji T-dependent. Berdasarkan uji normalitas diketahui hasil $P$ value $0,415>$ a $(0,05)$ dan terlihat bahwa data berdistribusi normal sehingga syarat penggunaan uji T-dependent terpenuhi.

Tabel 4.4

Hasil analisis mual muntah sebelum dan sesudah diberikan intervensi pada ibu hamil trimester I

\begin{tabular}{llllllll}
\hline Intervensi & Mean & $\mathbf{N}$ & \multicolumn{2}{c}{$\begin{array}{c}\text { Perbedaan } \\
\text { Mean }\end{array}$} & SD & SE & $\begin{array}{l}\boldsymbol{P} \\
\text { value }\end{array}$ \\
& & & & & & & \\
Sebelum & 10.93 & 15 & 7.60 & 1.40 & 1.43 & 0.37 & 0,000 \\
Sesudah & 3.33 & 15 & & & 0.61 & 0.15 & \\
\hline
\end{tabular}

Berdasarkan tabel 4.4 diatas didapatkan hasil sebelum dilakukan intervensi 10,93 dengan standar deviasi 0,37. Dan setelah dilakukan intervensi didapatkan hasil 3,33 dengan standar deviasi 0,61. Terjadi penurunan rerata sebelum dan sesudah intervensi adalah 7,60 dengan standar deviasi 1,40 . Hasil uji statistik didapatkan nilai $p 0,000>$ $(0,05)$ sehingga dapat disimpulkan bahwa pemberian permen jahe efektif dalam penurunan mual muntah pada ibu hamil trimester pertama.

\section{PEMBAHASAN}

Hasil penelitian menunjukkan bahwa sebagian besar responden berusia 20-35 tahun sebanyak 12 orang (80,0\%). Beberapa penelitian menyebutkan bahwa semakin tua usia seseorang maka, semakin jarang dia akan mengalami mual muntah. Hal ini disebabkan karena yang berusia tua telah mempunyai pengalaman dalam mengatasi mual muntah, sedangkan pada usia muda belum mampu mengatasi karena sebagian besar merupakan kehamilan pertama (Putri, Ayu 2016).

Berdasarkan karakteristik pendidikan sebagian besar responden berpendidikan SMA sebanyak 14 orang (93,3\%). Tingkat pendidikan berhubungan dengan kemampuan menerima informasi kesehatan dari media massa dan petugas kesehatan.

Hasil penelitian menunjukkan bahwa sebagian besar pekerjaan responden adalah ibu rumah tangga sebanyak 13 orang (86,7\%). Pada wanita hamil yang berada diantara keluarga atau dalam rutinitas kerja (Chittuma, 2007). Kecemasan terhadap situasi keuangan saat ini dan akan datang dapat menyebabkan kekhawatiran tambahan yang membuat wanita merasa tidak sehat. Jadi dengan pekerjaan sebagai ibu rumah tangga yang tidak dapat membantu perekonomian keluarga dapat maka ibu hamil dapat menyebabkan kekhawatiran tambahan yang membuat wanita merasa tidak sehat sehingga menimbulkan mual muntah pada kehamilannya (Tiran, 2013).

Sebagian besar responden belum memiliki anak dan merupakan kehamilan yang pertama yaitu sebanyak 8 orang (53,3\%). Gravida juga dapat mempengaruhi kejadian mual muntah. Sesuai dengan teori Tiran (2013) Peningkatan kejadian mual muntah terjadi pada perempuan yang baru pertama kali mengalami kehamilan (Primigravida) di banding perempuan yang telah mengalami beberapa kali kehamila (Multigravida). Hal ini disebabkan karena pada sebagian besar primigravida belum mampu beradaptasi dengan hormon estrogen dan koreonikgonadotropin sehingga lebih sering terjadi emesisgravidarum. Sedangkan pada multigravida dan grandemultigravida sudah mampu beradaptasi dengan hormon estrogen dan koreonikgonadotropin karena sudah mempunyai pengalaman terhadap kehamilan dan melahirkan. Pada primigravida menunjukkan kurangnya pengetahuan, informasi dan komunikasi yang buruk antara wanita dan pemberi asuhannya turut mempengaruhi persepsi wanita tentang gejala mual dan muntah. Sedangkan pada multigravida dan grandemultigravida sudah mempunyai pengalaman, informasi dan pengetahuan tentang gejala emesis gravidarum sehingga mampu mengatasi gejalanya.

Berdasarkan hasil penelitian didapatkan bahwa rata-rata mual muntah sebelum diberikan intervensi yaitu 10,93 dan setelah dilakukan intervensi pemberian permen jahe untuk dikonsumsi selama 4 hari dan dilakukan pengukuran kembali didapatkan nilai mual muntah yaitu 3.33 dengan nilai mean 7.60 . Data tersebut menunjukan bahwa pemberian permen jahe efektif dalam penurunan mual muntah pada ibu hamil trimester pertama.

Hasil penelitian ini didukung oleh penelitian yang dilakukan oleh Nugrahani (2015) tentang efektifitas pemberian seduhan jahe dengan jus buah jeruk bali terhadap frekuensi mual muntah ibu hamil trimester I, menemukan bahwa hasil analisis seduhan jahe dan jus buah jeruk bali pada ibu trimester I di wilayah kerja puskesmas Adan - Adan Kabupaten Kediri dengan menggunakan uji statistik Independent T-Test, rata rata frekuensi mual dan muntah responden sesudah diberikan seduhan jahe sebesar 1,62. Sedangkan rata rata frekuensi mual muntah pada responden yang diberikan jus buah jeruk bali sebesar 2,00. Sehingga dapat disimpulakan bahwa pemberian seduhan jahe lebih efektif dibandingkan pemberian jus buah jeruk bali. Menurut penelitian yang juga dilakukan oleh Ardani, Ayu (2014) tentang perbandingan efektifitas pemberian terapi minuman jahe dengan minuman kapulaga terhadap morning sickness pada ibu hamil trimester I, menemukan bahwa hasil uji statistik menunjukkan rata-rata tingkat morning sickness ibu hamil sesudah diberikan terapi minuman jahe sebesar 7,5. Nilai ini lebih rendah dibandingkan nilai rata-rata tingkat morning sickness sesudah diberikan terapi minuman kapulaga sebesar 9,93. Dengan nilai p-valeu sebesar $0,005<\alpha(0,05)$, maka dapat disimpulkan bahwa ada perbedaan secara bermakna efektifitas terapi minuman jahe dengan terapi minuman kapulaga terhadap morning sickness pada ibu hamil trimester I. Dalam penelitian lainnya oleh Putri, Ayu (2016) 
tentang efektifitas pemberian jahe hangat dalam mengurangi frekuensi mual muntah pada ibu hamil trimester I, menemukan bahwa hasil penelitian menunjukkan rata-rata frekuensi mual muntah sebelum diberikan minuman jahe hangat yaitu sebanyak 13 kalidan setelah diberikan menurun menjadi 3,18 kali. Hasil uji menunjukkan bahwa minuman jahe hangat efektif dalam mengurangi mual muntah pada ibu hamil $(p=0,000)$.

Hasil penelitian ini juga sesuai dengan teori Tiran (2013), mual muntah merupakan salah satu gejala paling awal, paling umum dan paling menyebabkan stres yang dikaitkan dengan kehamilan. Mual dan muntah sering kali diabaikan karena dianggap sebagai sebuah konsekuensi normal diawal kehamilan tanpa mengakui dampak hebat yang ditimbulkannya pada wanita dan keluarga mereka. Bagi beberapa wanita, gejala dapat berlangsung sepanjang hari, atau mungkin tidak terjadi sama sekali pada saat bangun tidur dipagi hari. Mual dan muntah selama kehamilan biasanya disebabkan oleh perubahan dalam sistem endokrin yang terjadi selama kehamilan, terutama disebabkan oleh tingginya fluktasi kadar HCG (human chorionic gonadotrophin), khususnya karena periode mual atau muntah gestasional yang paling umum adalah pada 1216 minggu pertama, yang pada saat itu, HCG mencapai kadar tingginya.

Menurut Rofi'ah, Handayani, Rahmawati (2017) Terapi awal pada emesis sebaiknya konservatif disertai dengan perubahan diet, dukungan emosional, dan terapi alternatif seperti herbal. Ramuan tradisional bisa digunakan dengan meminum secangkir jahe hangat. Di India, jahe dibuat sebagai minuman untuk mengatasi rasa mual pada wanita hamil. Jahe dapat dikonsumsi dalam berbagai bentuk seperti minuman, permen, atau manisan.

Penelitian ini sesuai dengan pernyataan Vutyavanich (2001 dalam Tiran, 2008) bahwa jahe merupakan pengobatan yang efektif untuk meredakan mual muntah dalam kehamilan. Jenis penyakit yang dapat diatasi dengan jahe antara lain : sakit kepala, pusing-pusing, penambah nafsu makan, dan muntahmuntah. Menurut Budhwaar (2006 dalam Fitri, Rahmi 2013), Salah satu fungsi farmakologis jahe adalah antiemetik (anti muntah), merupakan bahan yang mampu mengeluarkan gas dari dalam perut, hal ini akan meredakan perut kembung, juga merupakan stimulan aromatik yang kuat, disamping dapat mengendalikan muntah dengan meningkatkan gerakan peristaltik usus. Sekitar 6 senyawa di dalam jahe telah terbukti memiliki aktivitas antiemetik (anti muntah) yang manjur. Kerja senyawa-senyawa tersebut lebih mengarah pada dinding lambung dari pada system saraf pusat.

Menurut teori Sasmito, E (2017) Jahe biasanya aman sebagai obat herbal. Jahe tidak memiliki ketoksisitas akut pada dosis yang biasa dikonsumsi untuk makanan ataupun obat. Pada dosis yang besar yaitu $6 \mathrm{~g}$ atau lebih, rimpang jahe dapat menyebabkan iritasi lambung dan hilangnya mukosa pelindung lambung. Pada dosis normal (sampai 2 g sehari), jahe tidak mempengaruhi parameter pembekuan darah atau koagulasi darah.

Menurut asumsi peneliti permen jahe efektif dalam penurunan mual muntah pada ibu hamil trimester pertama. Dimana mual muntah disebabkan oleh perubahan pada sistem endokrin yang terjadi selama kehamilan, terutama disebabkan oleh tingginya fluktuasi kadar HCG (human chorionic gonadotrophin), khusunya pada periode mual atau muntah gestasional yang paling umum adalah pada 1216 minggu pertama. Sementara pada permen jahe yang berbahan dasar jahe didalamnya terdapat terdapat kandungan senyawa kimia yang mana rasa pedas yang terkandung pada jahe disebabkan oleh zat zingerone, sedangkan aroma khas yang ada pada jahe disebabkan oleh zat zingiberol. Dimana jahe dapat bekerja menghambat reseptor serotonin dan menimbulkan efek antiemetik pada sistem gastrointestinal dan sistem susunan saraf pusat. Jahe juga mempunyai kandungan minyak atsiri yang berfungsi sebagai anti radang, sehingga jahe dapat menghambat proses peradangan yang disebabkan oleh infeksi H.pylori. oleh karena itu, frekuensi mual muntah yang disebabkan oleh infeksi H.pylori dapat dikurangi. Maka dapat disimpulkan bahwa permen jahe efektif dalam penurunan mual muntah pada ibu hami trimester pertama, asumsi peneliti terbukti dalam penelitian ini dengan hasil penelitian $p<0,05$.

\section{KESIMPULAN}

Sebanyak 15 responden yang mengalami mual muntah sebelum intervensi dan dilakukan pengukuran dengan menggunakan kuesioner PUQE, mayoritas responden termasuk dalam kategori mual muntah berat sebanyak 13 orang dan dilakukan pengukuran kembali setelah intervensi didapatkan mayoritas responden berada dalam kategori tidak muntah sebanyak 11 orang.

Frekuensi mual muntah responden sebelum diberikan intervensi yaitu 10,93 dan setelah diberikan intervensi yaitu 3,33 dengan penurunan rata-rata 7,60. Hasil uji statistik didapatkan nilai $p<(0,05)$ sehingga dapat disimpulkan bahwa pemberian permen jahe efektif dalam penurunan mual muntah pada ibu hamil trimester pertama.

Disarankan Bagi Institusi Pendidikan diharapkan pihak institusi menyediakan lahan untuk dapat mambudidayakan tanaman jahe disekitar kampus dan berkerjasama dengan jurusan pertanian, dan hasilnya dapat diolah menjadi permen jahe. Untuk pengolahan permen jahe tersebut diharapkan pihak institusi berkolaborasi dengan jurusan farmasi sehingga hasil olahan nantinya dapat dikembangkan sebagai suatu kewirausahaan dalam jurusan khusus nya jurusan kebidanan.

Bagi Klinik Khairunida Kepada klinik Khairunida disarankan untuk memanfaatkan tanaman jahe sebagai tanaman yang dapat diolah menjadi permen guna menurunkan kejadian mual muntah pada ibu hamil trimester pertama. 


\section{DAFTAR PUSTAKA}

Ardani, Ayu. 2014. Perbandingan Efektifitas Pemberian Terapi Minuman Jahe dengan Minuman Kapulaga Terhadap Morning Sickness pada Ibu Hamil Trimester I di Kelurahan Ngempong Kecamatan Bergas Kabupaten Semarang.

Asrinah., dkk. 2015. Asuhan Kebidanan Masa Kehamilan. Yogyakarta : Graha Ilmu.

Fitria, Rahmi, 2013. Efektifitas jahe untuk menurunkan mual muntah pada kab. Serdang bedagai. Jurnal Maternity and Neonatal Vol 1 No 2

Kemenkes. 2016. Folmarium Obat Herbal Asli Indonesia. Jakarta. Sekretariat Jendral Kementrian Kesehatan RI.

2014. Profil Kesehatan Sumatera Utara 2015. http://www.depkes.go.id/resources/download/profi 1/PROFIL_KES_PROVINSI_2015/02_Sumut_201 4.pdf.

. 2015. Profil Kesehatan Indonesia Tahun 2015. Jakarta : Sekretariat Jendral Kementrian Kesehatan RI. http://www.dep kes.go.id/resources/download/pusdatin/profilkesehatan-indonesia/profil-kesehatan-indonesia2015.pdf.

Mandriwati, G.A., dkk. 2016. Asuhan Kebidanan Kehamilan Berbasis Kompetensi. Jakarta : Penerbit Buku Kedokteran EGC.

Marlina, Hastuti., dan Nurul. 2016. Manfaat Permen Jahe dan Permen Mint dalam Mengatasi Hiperemesis Gravidarum pada ibu hamil di Wilayah Kerja Puskesmas Sidomulyo Pekanbaru.

Machfoedz, Irham. 2010. Metodologi Kesehatan. Yogyakarta : Fitra Maya.

Notoatmodjo, Soekidjo. 2010. Metodologi Penelitian Kesehatan. Jakarta : Rineka Cipta.
Nugrahani, Rosi. 2015. Efektifitas Pemberian Seduhan Jahe Dengan Jus Buah Jeruk Bali Terhadap Frekuensi Mual Muntah Ibu Hamil Trimester I. Prosiding Seminar Nasional Kesehatan Jilid I, hlm 27-37.

Prawirohardjo, Sarwono. 2013. Ilmu Kebidanan. Jakarta : PT Bina Pustaka.

Putri, Ayu., D Andiani dan Haniarti. 2016. Efektifitas Pemberian Jahe Hangat Dalam Mengurangi Frekuensi Mual Muntah Pada Ibu Hamil Trimester I. Prosiding Seminar Nasional IKAKESMADA "Peran Tenaga Kesehatan dalam Pelaksanaan SDGs".

Rofi'ah., dan Handayani, Rahmawti. 2017. Efektifitas Konsumsi Jahe dan Sereh dalam Mengatasi Morning Sickness. JURNAL ILMIAH BIDAN , VOL.II, NO.2, 2017

Sasmito, E. 2017. IMUNOMODULATOR Bahan Alami. Bandung. ANDI OFFSET

Sulistyawati, Ari. 2015. Asuhan Kebidanan Pada Masa Kehamilan. Jakarta : Salemba Medika.

Tiran, Denise. 2013. Mual dan muntah Kehamilan. Jakarta : EGC.

World Health Organization (WHO). 2015. http://apps.w ho.int/iris/bitstream/10665/170250/1/97892406944 39_eng.pdf (diakses 03 Maret 2018). 